\title{
In Silico Analysis of Resistance Gene Identifiers on Plasmids of blaNDM-5 Producing Carbapenem-Resistant Escherichia coli Strains Isolated in Humans and Animals
}

\author{
Mehmet Demirci' ${ }^{1}$ Akın Yigin², Seda Ekici ${ }^{*}$ \\ ${ }^{1}$ Kirklareli University, Faculty of Medicine, Department of Medical Microbiology, Kirklareli, Turkey \\ ${ }^{2}$ HarranUniversity, Faculty of Veterinary, Department of Genetics, Sanliurfa, Turkey \\ ${ }^{3}$ Veterinary Control Central Research Institute, Ankara, Turkey
}

\begin{abstract}
Due to their ability to resist endpoint antimicrobials such as carbapenem, it is very important to detect and monitor multi-drug resistant Gram negative strains with plasmids containing genes such as blaNDM-5 by new molecular methods. This study aimed to perform in silico analysis of resistance gene identifiers on human and animal-derived blaNDM- 5 plasmids found in open databases, which were analyzed by new whole genome sequencing techniques and to compare these resistance genes. The plasmid genomic sequences of 4 human and 2 animal E. coli strains containing blaNDM-5 genes included in our study were analyzed in Silico using the Resistance Gene Identifier (RGI) option of the comprehensive antibiotic resistance gene database using default values. Human and animal strains included in our study were found to have different antimicrobial resistance genes in addition to blaNDM-5. All plasmids were found to have at least 8 perfect antimicrobial resistance gene sequences matches. When the resistance gene identifiers in all plasmids were examined, 35 resistance gene identifiers were found. Besides blaNDM-5, mphA, qacEdelta1 and sul1 were found in all plasmids. As a conclusion, it was determined by our study results that, regardless of the source, there may be different antimicrobial resistance gene identifiers besides the blaNDM5 resistance gene in plasmids. We are of the opinion that routine molecular surveillance studies should be carried out considering the one health approach of Gram-negative pathogens such as E. coli, which can contain plasmids that cause multidrug resistance and can be isolated from all sources.
\end{abstract}

Key words: blaNDM-5, Carbapenem resistant E.coli, in silico analysis, resistance gene identifier.

İnsanlardan ve Hayvanlardan İzole Edilen blaNDM-5 Üreten Karbapenem Dirençli Escherichia coli Kökenlerinin Plazmidlerı Üstünde Bulunan Direnç Gen Tanımlayıcılarının İn Silico Analizi

ÖZ

Karbapenem gibi son nokta antimikrobiyallere direnç yetenekleri dolayısıyla, blaNDM-5 gibi genler ihtiva eden plazmidlere sahip çoklu ilaç direnci gösteren Gram negatif kökenlerin yeni moleküler yöntemlerle tespiti önemlidir. Biz de çalışmamızda bu yeni tekniklerle tüm genom sekans analizi yapılan ve açık veritabanlarında bulunan insan ve hayvan kaynaklı blaNDM-5 plazmidleri üstünde bulunan direnç gen tanımlayıcılarının in silico analizini yapmayı ve bu direnç genlerini karşılaştırmayı amaçladık. Çalışmamıza dahil edilen 4 insan ve 2 hayvan kaynaklı, blaNDM-5 geni içeren E.coli kökenlerine ait plazmid genomik dizileri, varsayılan değerler kullanılarak kapsamlı antibiyotik direnç gen veritabanının, direnç geni tanımlayıcı (RGI) seçeneği kullanılarak bilgisayar ortamında analiz edildi. Çalışmamıza dahil edilen insan ve hayvan kaynaklı kökenlerde blaNDM-5 yanında farklı antimikrobiyal direnç genlerinin de olduğu tespit edildi. Tüm plazmidlerin en az 8 mükemmel antimikrobiyal direnç gen dizisi eşleşmesi gösterdiği saptandı. Tüm plazmidlerde bulunan direnç gen tanımlayıcıları incelendiğinde 35 direnç gen tanımlayıcısı saptandı. blaNDM-5 yanında, mphA, qacEdelta1 ve sul1'in bütün plazmidlerde olduğu tespit edildi. Sonuç olarak, kaynak fark etmeksizin, plazmidlerde, blaNDM-5 direnç geni yanında farklı antimikrobiyallere direnç gen tanımlayıcılarının da olabildiği çalışma sonucunda tespit edilmiştir. Çoklu ilaç direncine neden olan plazmidleri ihtiva edebilen ve tüm kaynaklardan izole edilebilen E. coli gibi Gram negatif patojenler üzerinde tek sağlık yaklaşımı düşünülerek rutin moleküler surveyans çalışmalarının yapılması gerektiği kanaatindeyiz.

Anahtar Kelimeler: blaNDM-5, direnç gen tanımlayıcıları, in silico analiz, Karbapenem dirençli E.coli

To cite this article: Demirci M. Yigin A. Ekici S. In Silico Analysis of Resistance Gene Identifiers on Plasmids of blaNDM-5 Producing Carbapenem-Resistant Eschericbia coli Strains Isolated in Humans and Animals. Kocatepe Vet J. (2021):14(3):303-308

Submission: 24.05.2021 Accepted: 18.08.2021 Published Online: xx.x.2021

ORCID ID; MD: 0000-0001-9670-2426, AY: 0000-0001-9758-1697, SE: 0000-0002-7982-5261

*Corresponding author e-mail: seda.ergen@hotmail.com 


\section{INTRODUCTION}

Antimicrobial resistance is a huge threat to public health around the world. Carbapenems; are last-resort treatment options against infections with Cephalosporinase and/or extended spectrumlactamase producing Gram-negative pathogens showing multi-drug resistance, including Enterobacteriaceae (Huang et al. 2021). These bacteria can produce different carbapenemases to inactivate carbapenems ; Of these, New Delhi Metallo- $\beta$ lactamase $(\mathrm{NDM})$ is one of the newly emerging and of serious clinical importance (Zhu et al. 2016). NDM-1 was first identified from a Klebsiella pneumoniae strains in India in 2008 (Young et al. 2009). 29 NDM variants have been reported in a short time (Basu, 2020). NDM-5 was discovered in a multi-resistant Escherichia coli (E.coli) strains in the United Kingdom in 2011 (Hornsey et al. 2011). It differs two amino acid (Val88Leu and Met154Leu) changes with NDM-1 and appears to confer increased resistance to extendedspectrum cephalosporins and carbapenems. The coding of the blaNDM-5 gene in isolates is defined (Zhu et al. 2016). It has been reported that blaNDM-5 is carried in different incompatible type plasmids for transfer, such as IncF, IncN, and IncX3. These plasmids can facilitate the spread of blaNDM- 5 among Enterobacteriaceae members through horizontal gene transfer (Li et al. 2018). E. coli strains showing multidrug resistance and producing blaNDM-5 plasmid were identified in human, animal, and food isolates, and plasmids in these strains were sequenced using the whole genome sequencing style (He et al. 2017, Feng et al. 2018, Liu et al. 2018, Xie et al. 2018, Tyson et al. 2019, Marchetti et al. 2020). It is important to determine the survelliance of the resistance profiles of the strains obtained from different disciplines in a one health approach (Aenishaenslin et al. 2021). In our study, we aimed to examine the in silico analysis of resistance gene identifiers with human and animal blaNDM-5 plasmids in the open database and to compare these resistance genes.

\section{MATERIALS and METHODS}

\section{Plasmid database}

In our study, the plasmid genomic sequences of E.coli strains of the blaNDM-5 gene whose sequencing has been completed with the whole genome analysis in the $\mathrm{NCBI}$ open database, the valid values were used in the comprehensive antibiotic resistance gene database (CARD - https://card.mcmaster.ca/analyze/rgi) in resistance gene identifier (RGI) option and in silico analysis was performed. The Comprehensive Antibiotic Resistance Database ("CARD") that provides molecular data and algorithms on key gene markers of antimicrobial resistance was used. The CARD online software provides reference gene sequences and analysis of SNPs in genetic sequences through Antibiotic Resistance Ontology ("ARO"). Resistance gene identifiers (RGI) obtained through the models obtained from the sequencing analysis data can be used for resistome prediction (Alcock et al, 2020). The identified resistance gene were compared in human and animal isolates.

\section{RESULTS}

Information on human and animal sources included in our study are summarized in Table1. After RGI analysis of all genome sequence sequences, it was observed that there are different resistance genes in addition to blaNDM-5 in human and animal sources. It was determined that at least 8 of the resistance gene identifiers in all plasmids showed a perfect $(100 \%)$ sequence match. Minimum inhibitory concentration (MIC) values for these carbapenem-resistant isolates were also examined and presented in Table1 and Figure1.

When the resistance gene identifiers in all plasmids were examined, 35 resistance gene identifiers were found. Except for blaNDM-5, mphA, qacEdelta1 and sull were found in all strains. All genes identified in Table2 are presented comparatively according to human and animal sources. Ten genes causing aminoglycoside resistance were detected on the NDM5 gene carrying plasmid. It was determined that $50 \%$ of the plasmids of both human and animal strains carried an important antimicrobial resistance gene such as blaCTX-M-15. 
Table1. RGI analysis of whole genome analyzed plasmids containing the blaNDM-5 gene.

\begin{tabular}{|c|c|c|c|c|c|c|c|}
\hline $\begin{array}{l}\text { NCBI } \\
\text { accession } \\
\text { number }\end{array}$ & $\begin{array}{l}\text { The living } \\
\text { thing from } \\
\text { which the } \\
\text { origin is } \\
\text { isolated }\end{array}$ & Insulation Material & $\begin{array}{l}\text { Carbapenem } \\
\text { MIC }\end{array}$ & $\begin{array}{l}\text { Perfect } \\
\text { Sequence } \\
\text { Match }\end{array}$ & $\begin{array}{l}\text { Strict } \\
\text { Sequence } \\
\text { Match }\end{array}$ & $\begin{array}{l}\text { Loose } \\
\text { Sequence } \\
\text { Match }\end{array}$ & References \\
\hline CP041393 & DOG & & 4 & 10 & 3 & 5 & 7 \\
\hline KY990887 & COW & Endotracheal Washing Fluid & 64 & 10 & 5 & 5 & 10 \\
\hline MN218686 & HUMAN & Cow stool material & 16 & 8 & 7 & 6 & 8 \\
\hline MN197360 & HUMAN & $\begin{array}{l}\text { Stool material obtained from } \\
\text { the baby }\end{array}$ & 16 & 9 & 2 & 2 & 8 \\
\hline CP023871 & HUMAN & $\begin{array}{l}\text { Stool material obtained from } \\
\text { the baby }\end{array}$ & 64 & 15 & 2 & 8 & 9 \\
\hline MF679147 & HUMAN & Urine material & 16 & 8 & 3 & 8 & 11 \\
\hline
\end{tabular}

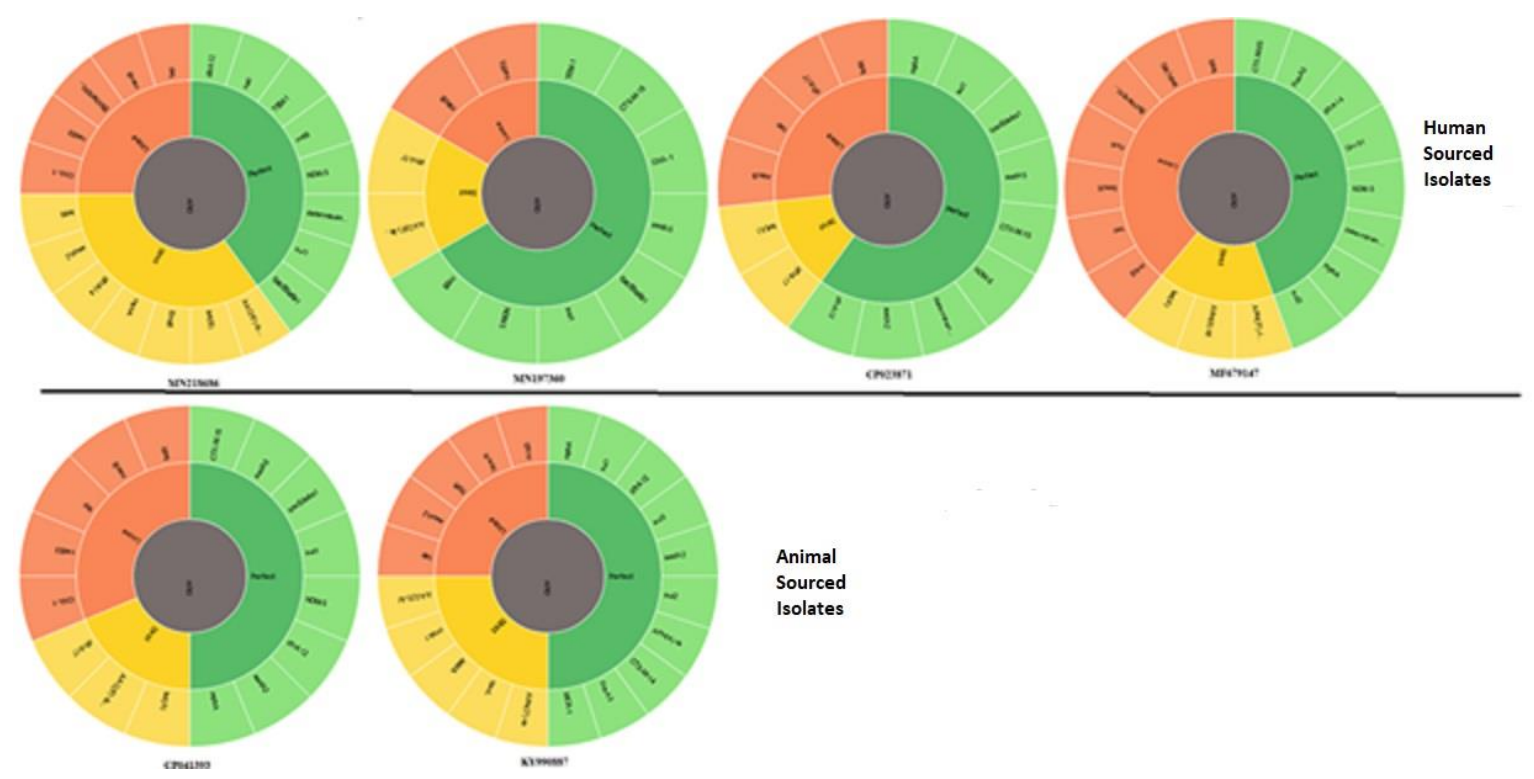

Figure1: Distribution of resistance gene identifiers obtained from whole genome sequencing data of plasmids carrying with carbapenem resistant blaNDM-5 gene. (Green:Perfect Sequence Match, Red: Strict Sequence Match, and Yellow:Loose Sequence Match). 
Table2. Genus of gene identifiers found in plasmids detected in human and animal isolates.

\begin{tabular}{|c|c|c|c|c|c|}
\hline $\begin{array}{l}\text { Gene name } \\
\text { detected on the } \\
\text { plasmid }\end{array}$ & Antimicrobial (s) on which it acts & $\begin{array}{l}\text { human source } \\
(n: 4)\end{array}$ & $\begin{array}{l}\text { Percentage } \\
(\%) \text { of } \\
\text { matching } \\
\text { region in } \\
\text { human- } \\
\text { derived } \\
\text { plasmids }\end{array}$ & $\begin{array}{l}\text { Animal source } \\
(\mathrm{n}: 2)\end{array}$ & $\begin{array}{l}\text { Percentage } \\
(\%) \text { matched } \\
\text { region in } \\
\text { animal derived } \\
\text { plasmids }\end{array}$ \\
\hline AAC(3)-IV & aminoglycoside & $0(\% 0)$ & & $1(\% 50)$ & 99.61 \\
\hline AAC(6')-Ib-cr & fluoroquinolone, aminoglycoside & $2(\% 50)$ & 98.99 & $1(\% 50)$ & 98.99 \\
\hline $\operatorname{aadA}$ & aminoglycoside & $0(\% 0)$ & & $1(\% 50)$ & 99.61 \\
\hline aadA2 & aminoglycoside & $2(\% 50)$ & 99.8 & $2(\% 100)$ & 100 \\
\hline aadA5 & aminoglycoside & $3(\% 75)$ & 100.0 & $1(\% 50)$ & 100.0 \\
\hline APH(3')-Ia & aminoglycoside & $0(\% 0)$ & & $1(\% 50)$ & 98.52 \\
\hline APH(3")-Ib & aminoglycoside & $1(\% 25)$ & 99.63 & $0(\% 0)$ & \\
\hline APH(4)-Ia & aminoglycoside & $0(\% 0)$ & & $1(\% 50)$ & 100 \\
\hline APH(6)-Id & aminoglycoside & $1(\% 25)$ & 99.28 & $0(\% 0)$ & \\
\hline blaCTX-M-14 & Cephalosporin & $0(\% 0)$ & & $1(\% 50)$ & 100 \\
\hline blaCTX-M-15 & Cephalosporin & $2(\% 50)$ & 100 & $1(\% 50)$ & 100 \\
\hline blaCTX-M-65 & Cephalosporin & $1(\% 25)$ & 100 & $0(\% 0)$ & \\
\hline blaNDM-5 & $\begin{array}{l}\text { carbapenem, } \\
\text { cephamycin, penam }\end{array}$ & $4(\% 100)$ & 100 & $2(\% 100)$ & 100 \\
\hline blaOXA-1 & carbapenem, cephalosporin, penam & $1(\% 25)$ & 100 & $0(\% 0)$ & \\
\hline blaTEM-1 & $\begin{array}{l}\text { monobactam, cephalosporin, penam, } \\
\text { penem }\end{array}$ & $2(\% 50)$ & 100.0 & $0(\% 0)$ & \\
\hline BRP(MBL) & Glycopeptide & $3(\% 75)$ & 100 & $0(\% 0)$ & \\
\hline catI & Phenycol & $1(\% 25)$ & 100 & $0(\% 0)$ & \\
\hline cmlA1 & Phenycol & $0(\% 0)$ & & $1(\% 50)$ & 99.76 \\
\hline dfrA12 & Diaminopyrimidine & $2(\% 50)$ & 100 & $2(\% 100)$ & 100 \\
\hline dfrA14 & Diaminopyrimidine & $2(\% 50)$ & 99.68 & $0(\% 0)$ & \\
\hline dfrA17 & Diaminopyrimidine & $2(\% 50)$ & 99.36 & $1(\% 50)$ & 99.36 \\
\hline ErmB & macrolide,lincosamide, streptogramin & $1(\% 25)$ & 97.96 & $0(\% 0)$ & \\
\hline FosA3 & fosfomycin & $1(\% 25)$ & 100 & $1(\% 50)$ & 100 \\
\hline MCR-1.1 & peptide antibiotic & $0(\% 0)$ & & $1(\% 50)$ & 100 \\
\hline mphA & macrolide & $4(\% 100)$ & 100 & $2(\% 100)$ & 100 \\
\hline qacEdelta1 & acridine paint & $4(\% 100)$ & 100 & $2(\% 100)$ & 100 \\
\hline qacL & quaternary ammonium compound & $0(\% 0)$ & & $1(\% 50)$ & 93.64 \\
\hline QnrS1 & Fluoroquinolone & $1(\% 25)$ & 100 & $0(\% 0)$ & \\
\hline rmtB & aminoglycoside & $2(\% 50)$ & 100 & $0(\% 0)$ & \\
\hline sul1 & sulfonamide & $4(\% 100)$ & 100 & $2(\% 100)$ & 100 \\
\hline sul2 & sulfonamide & $1(\% 25)$ & 100 & $1(\% 50)$ & 100 \\
\hline sul3 & sulfonamide & $0(\% 0)$ & & $1(\% 50)$ & 100 \\
\hline $\operatorname{tet}(\mathrm{A})$ & Tetracycline & $2(\% 50)$ & 99.74 & $1(\% 50)$ & 99.74 \\
\hline $\operatorname{tet}(\mathbf{B})$ & Tetracycline & $1(\% 25)$ & 99.25 & $0(\% 0)$ & \\
\hline tetR & Tetracycline & $1(\% 25)$ & 100 & $0(\% 0)$ & \\
\hline
\end{tabular}


Carbapenems are a class of beta-lactam antibiotics that are active against many aerobic and anaerobic Grampositive and Gram-negative organisms. They are critically important antibiotics used to treat serious bacterial infections. Carbapenem resistance is rare and typically results from the production of a carbapenemase enzyme that can hydrolyze penicillins, cephalosporins, monobactams and carbapenems (Tyson et al. 2019). The presence of plasmids that carry the NDM-5 gene can create Pan-resistant E. coli strains (He et al. 2017). Moreover, these plasmids can be transferred by conjugation, which has shown that they can be self-infectious (Feng et al. 2018). When the studies on carbapenem resistant $E$. coli strains producing blaNDM-5 were examined; Sun et al. reported in their study in 2019 that they detected blaCTX-M-15 and blaCTX-M-14 genes as well as $\mathrm{rmtB}$ and aac (6')-Ib-cr genes in human sources, in addition to blaNDM-5 (Sun et al. 2019). Similarly, among the plasmids we examined in our study, we found that $\mathrm{rmtB}$ and aac (6)-Ib-cr genes were detected more frequently, especially in human sources. While blaCTX-M-15 was detected in human and animal sources, blaCTX-M-14 gene was not detected in human sources. Sun et al. reported that they detected the blaCTX-M-64 gene in some of their strains [14]. We could not detect the blaCTX-M-64 gene in our study. Brown et al. (2018) reported that they detected the blaCTX-M-65 gene in Salmonella strains in chicken meat. In our study, we found that blaCTX-M65 gene was carried in a blaNDM-5 plasmid of E.coli strains obtained from a human sample. This has shown us that these genes can switch between bacterial species. Tian et al. (2020) reported that they detected $\operatorname{aadA2}$ and dfrA12 resistance gene cassettes in plasmids containing blaNDM-5, which they detected in children in their study in 2020. In our study, we found that both gene identifiers were found in sources similarly. While these genes were detected in $50 \%$ of our human sources, they were found in all of our animal sources. Ramadan et al., (2020) detected blaNDM-5 producing strains in humans and dogs. In the same study, they reported that they detected multiple resistance genes related to $\beta$-lactams, aminoglycosides, tetracyclines, quinolones, phenicols, macrolides and folate pathway inhibitors in all isolates. However, they did not find mcr genes in human or dog isolates in this study. In our in silico analysis, we detected the resistance genes for all these antimicrobials in strains from both human and animals. In addition, KY990887 (NCBI accession number), which was obtained from the cow feces samples was carried mor gene (He et al. 2017). E. coli strains carried NDM-5-plasmids with multi-drug resistance, including carbapenem, also reported from environmental sources (Zhao et al. 2021), nutritional sources (Liu et al. 2018) and waters (Liu et al. 2019) except humans and animals.
As a result, multi-drug resistant E. coli strains carried blaNDM-5 plasmids can be identified, regardless of the source. Our study results revealed that plasmids belonging to these strains may also have resistance gene identifiers against different antimicrobials in addition to the blaNDM-5 resistance gene. We conluded that routine molecular surveillance studies should be carried out, considering the onehealth approach for Gram-negative pathogens such as E. coli, which can carry different plasmids that cause multidrug resistance

Etik Kurul Bilgileri : Çalışma kapsamında etik kurul onay belgesine ihtiyaç bulunmamaktadır.

Ç1kar Çatışması: Yazarlar, çıkar çatışması olmadığını beyan eder.

\section{REFERENCES}

Aenishaenslin C, Häsler B, Ravel A, Parmley EJ, Mediouni S, Bennani H, Buckeridge DL. Evaluating the Integration of One Health in Surveillance Systems for Antimicrobial Use and Resistance: A Conceptual Framework. Frontiers In Veterinary Science. 2021;8, 169.

Alcock BP, Raphenya AR, Lau TTY, Tsang KK, Bouchard M, Edalatmand A, Huynh W, Nguyen AV, Cheng AA, Liu S, Min SY, Miroshnichenko A, Tran HK, Werfalli RE, Nasir JA, Oloni M, Speicher DJ, Florescu A, Singh B, Faltyn M, HernandezKoutoucheva A, Sharma AN, Bordeleau E, Pawlowski AC, Zubyk HL, Dooley D, Griffiths E, Maguire F, Winsor GL, Beiko RG, Brinkman FSL, Hsiao WWL, Domselaar GV, McArthur AG. CARD 2020: antibiotic resistome surveillance with the comprehensive antibiotic resistance database. Nucleic Acids Res. 2020;48:D517-D525.

Basu S. Variants of the New Delhi metallo- $\beta$-lactamase: New Kids On The Block 1. 2020 ; 465-467.

Brown AC, Chen JC, Watkins LKF, Campbell D, Folster JP, Tate H, Friedman CR. CTX-M-65 extended-spectrum $\beta$-lactamase-producing Salmonella enterica serotype Infantis, United States. Emerging Infectious Diseases. 2018; 24(12), 2284.

Feng Y, Liu L, McNally A, Zong Z. Coexistence of two blaNDM- 5 genes on an IncF plasmid as revealed by nanopore sequencing. Antimicrobial Agents And Chemotherapy. 2018 ; 62(5).

He T, Wei R, Zhang L, Sun L, Pang M, Wang R, Wang Y. Characterization of NDM-5-positive extensively resistant Escherichia coli isolates from dairy cows. Veterinary Microbiology. 2017; 207, 153-158.

Huang YS, Tsai WC, Li JJ, Chen PY, Wang JT, Chen YT, Chang SC. Increasing New Delhi metallo- $\beta$-lactamasepositive Escherichia coli among carbapenem non- 
susceptible Enterobacteriaceae in Taiwan during 2016 to 2018. Scientific Reports. 2021; 11(1), 1-10

Hornsey M, Phee L, Wareham DW. A novel variant, NDM-5, of the New Delhi metallo- $\beta$-lactamase in a multidrugresistant Escherichia coli ST648 isolate recovered from a patient in the United Kingdom. Antimicrobial Agents And Chemotherapy. 2011; 55(12), 5952-5954.

Li X, Fu Y, Shen M, Huang D, Du X, Hu Q, Yu Y. Dissemination of bla NDM-5 gene via an IncX3-type plasmid among non-clonal Escherichia coli in China. Antimicrobial Resistance \& Infection Control. 2018; 7(1), $1-9$.

Liu BT, Zhang XY, Wan SW, Hao JJ, Jiang RD, Song FJ. Characteristics of carbapenem-resistant Enterobacteriaceae in ready-to-eat vegetables in China. Frontiers In Microbiology. 2018; 9, 1147.

Liu Z, Xiao X, Li Y, Liu Y, Li R, Wang Z. Emergence of IncX3 Plasmid-Harboring blaNDM-5 Dominated by Escherichia coli ST48 in a Goose Farm in Jiangsu, China. Frontiers in microbiology. 2019;10, 2002.

Marchetti VM, Bitar I, Mercato A, Nucleo E, Bonomini A, Pedroni P, Migliavacca R. Complete Nucleotide Sequence of Plasmids of Two Escherichia coli Strains Carrying blaNDM-5 and blaNDM-5 and blaOXA-181 From the Same Patient. Frontiers In Microbiology. 2020; 10,3095 .

Ramadan H, Gupta SK, Sharma P, Ahmed M, Hiott LM, Barrett JB, Jackson CR. Circulation of emerging NDM5-producing Escherichia coli among humans and dogs in Egypt. Zoonoses And Public Health. 2020; 67(3), 324329

Sun P, Xia W, Liu G, Huang X, Tang C, Liu C, Pan S. Characterization of blaNDM-5-positive Escherichia coli prevalent in a university hospital in eastern China. Infection And Drug Resistance. 2019; 12, 3029.

Tian D, Wang B, Zhang H, Pan F, Wang C, Shi Y, Sun Y. Dissemination of the blaNDM-5 gene via IncX3-type plasmid among Enterobacteriaceae in children. Msphere. 2020; 5(1).

Tyson GH, Li C, Ceric O, Reimschuessel R, Cole S, Peak L, Rankin SC. Complete genome sequence of a carbapenem-resistant Escherichia coli isolate with blaNDM5 from a dog in the United States. Microbiology Resource Announcements. 2019; 8(34).

Yong D, Toleman MA, Giske CG, Cho HS, Sundman K, Lee K, Walsh TR. Characterization of a new metallo- $\beta$ lactamase gene, blaNDM-1, and a novel erythromycin esterase gene carried on a unique genetic structure in Klebsiella pneumoniae sequence type 14 from India. Antimicrobial Agents And Chemotherapy. 2009; 53(12), 5046-5054.

Xie M, Li R, Liu Z, Chan EWC, Chen S. Recombination of plasmids in a carbapenem-resistant NDM-5-producing clinical Escherichia coli isolate. Journal Of Antimicrobial Chemotherapy. 2018; 73(5), 1230-1234.
Zhao Q, Berglund B, Zou H, Zhou Z, Xia H, Zhao L, Li X. Dissemination of blaNDM-5 via IncX3 plasmids in carbapenem-resistant Enterobacteriaceae among humans and in the environment in an intensive vegetable cultivation area in eastern China. Environmental Pollution. 2021; 273, 116370.

Zhu YQ, Zhao JY, Xu C, Zhao H, Jia N, Li YN. Identification of an NDM-5-producing Escherichia coli sequence type 167 in a neonatal patient in China. Scientific Reports. 2016; 6(1), 1-8. 